\title{
Earnings Management Within Three Tax Reforms Era
}

\section{Astri Nur Perwita and Dian Anita Nuswantara}

\section{Abstract}

This study aims to examine and analyze the differences in the level of earnings management in companies going public in Indonesia in the three era of tax reform. The level of earnings management is measured using discretionary accruals. This study uses a sample of 77 companies listed on the Indonesia Stock Exchange during the research periods 1995, 2001, 2009, and 2010. Data were analyzed using one way analysis of variance (ANOVA). This study found that the level of earnings management in 1995 in which Law No. 10 of 1994 came into force showed a significant difference compared to the level of earnings management in 2001, 2009, and 2010.

Keywords: earnings management, accrual discretioner, tax reform, tax rate reduction

Corresponding Author:

Astri Nur Perwita

astri.perwita@gmail.com

Received: 29 January 2019

Accepted: 27 February 2019

Published: 24 March 2019

Publishing services provided by Knowledge E

(c) Astri Nur Perwita and Dian Anita Nuswantara. This article is distributed under the terms of the Creative Commons.

Attribution License, which permits unrestricted use and redistribution provided that the original author and source are credited.

Selection and Peer-review under the responsibility of the $3 \mathrm{rd}$ ICEEBA Conference Committee.

\section{Introduction}

Indonesia has undergone several changes to tax laws. Tax reform in Indonesia first began in 1983, marked by the issuance of Law Number 6 of 1983 concerning General Provisions and Procedures for Taxation and Law Number 7 of 1983 concerning Income Taxes. Subsequent changes to the Income Tax Law took place on 30 December 1991 with the issuance of Law Number 7 of 1991. Subsequently the third amendment took place on 9 November 1994 with the issuance of Law Number 10 of 1994 . The fourth amendment occurred on 2 August 2000 marked with the issuance of Law Number 17 of 2000. The latest reform of the Income Tax Law took place in 2008. This reform was marked by the issuance of Law Number 36 of 2008 concerning Income Tax. One of the changes to the Law was to set a tax rate lower new income. With this change, it is expected to increase state tax revenues. But in reality, the average state tax revenue is still below the target.

Decreasing corporate income tax rates can provide incentives for companies by transferring profits to periods where the corporate income tax rate is smaller. The tariff reduction supports companies as taxpayers to conduct earnings management with discretionary accruals thereby encouraging management to carry out opportunistic methods. (Ristiyanti \& Muchamad, 2012). Earnings management can be interpreted as a company 
activity to regulate profits to be reported to meet personal and/or company interests. The high profit achieved by a company makes the higher the tax that must be paid by the company as a taxpayer to the government.

Basically the government wants to collect taxes as high as possible because taxes are the highest source of state revenue, while management as a taxpayer certainly wants to pay taxes as little as possible because for management the tax imposed on income received or obtained can be considered as cost or expense in carrying out a business or conducting activities or distributing profits to the government (Smith and Skousen, 1987) in (Suandy, 2014: 5). This is in line with the research of Yulianti and Christine (2012) which prove that the average company conducts accrual policy which results in smaller profits in the period where the tax rate is lower. In addition, Ristiyanti and Syafruddin (2012) also revealed that companies that experience profits are proven to do earnings management when there is a decrease in tax rates.

Based on the description above, the study examines whether the difference in the level of earnings management is seen from changes in corporate tax rates divided into three categories, namely category 1 (one) for Law Number 10 of 1994, category 2 (two) for Law Number 17 Year 2000, and category 3 (three) for Law Number 36 Year 2008. Through this research, the researcher will analyze the practice of earnings management on each tax reform. So that this research is expected to be useful for the government as one of the bases for making decisions on the reduction in income tax rates in the next period.

\section{Theory}

\subsection{Agency theory}

According to Jensen \& Meckling (1976), agency relations can be defined as a collection of contracts between principal and agent. Where a collection of contracts (nexus of contract) consists of one or more people (principal) instructing another person (agent) to carry out a collaboration on behalf of the principal then the agent is given full authority to give a decision that is considered the best for the principal.

Agency theory can explain how companies as taxpayers carry out earnings management actions when tax reforms occur. The existence of changes in laws including a reduction in tariffs can make taxpayers avoid tax avoidance. With the reduction in rates, taxpayers are required to practice earnings management. So as to encourage management as an agent to carry out opportunistic methods to fulfill the interests of 
shareholders as principals. This opportunistic method is based on an opportunism in which there is a thought that requires the best use of profitable opportunities, for oneself, groups or certain purposes.

\subsection{Positive accounting theory}

A positive approach in accounting is to explain and predict management standard choices through analysis of the costs and benefits of certain financial disclosures in relation to individuals and allocation of economic resources (Belkaoui, 2007: 187). Positive approach seeks to determine various factors that influence rational factors in the field of accounting. Positive approaches are generally distinguished from normative stressors, who try to determine a theory that explains 'what should be' and 'not what is there'

\subsection{Indonesian tax reform}

The first Income Tax Law reform in Indonesia was marked by the issuance of Law Number 7 of 1983 and was enacted in 1984. Subsequently the second change occurred in 1991 when the government issued Law Number 7 of 1991. The third change occurred in 1994 with the issuance of Law Number 10 of 1994. The fourth amendment was marked by the issuance of Law Number 17 of 2000. The latest Income Tax Law reform was marked by the issuance of Law Number 36 of 2008.

The improvement of the Income Tax Law has the aim of further improving the fairness of tax imposition, giving more convenience to taxpayers, giving simplicity in tax administration, providing more legal certainty, consistency, and transparency, and more supporting government policies in order to increase internal competitiveness. attract direct investment in Indonesia, both foreign investment and domestic investment in certain business fields and certain areas that receive priority.

\subsection{Earnings management}

Sulistiawan et al. (2011: 3-4) states that the term earnings management is used for accounting practices that are done legally (not violating predetermined regulations). Motivation for tax savings is the most obvious motivation for earnings management. Such behavior is common in where human opportunists tend to get as much results as possible by issuing resources as low as possible. 
According to Sulistiawan et al. (2011: 70) a management measurement model that can be used one of them is the Modified Jones Model (1995) developed by Dechow and colleagues (1995). Modified Jones Model (1995) is a refinement of the Jones Model which, according to Dechow and friends, has weaknesses implicitly assuming that management discretion is not done on income. In fact, income is not completely separated from the effort of manipulation. If the company manager turns out to do manipulation through income, the Jones Model becomes possible. Determination of the Modified Jones Model as an indicator of earnings management is described in the following stages:

1. Determine the total accrual value (TA)

$$
\mathrm{TA}_{\mathrm{it}}=\mathrm{Ni}_{\mathrm{it}}-\mathrm{CFO}_{\mathrm{it}}
$$

2. Determine the parameter values $\alpha 1, \beta 1$, and $\beta 2$ use Jones Model (1991)

$$
\mathrm{TA}_{\mathrm{it}}=\alpha_{1}+\alpha_{2} \Delta \mathrm{R}_{\mathrm{evit}}+\alpha_{3} \mathrm{PPE}_{\mathrm{it}}
$$

Then, for the scale of the data, all these variables are shared with the assets of the previous year $\left(\mathrm{A}_{i t-1}\right)$

$$
\left.\mathrm{TA}_{\mathrm{it}} / \mathrm{A}_{\mathrm{it}-1}=\alpha_{1}\left(1 / A_{\mathrm{it}-1}\right)+\alpha_{2} \Delta \mathrm{R}_{\text {evit }} / \mathrm{A}_{\mathrm{it}-1}\right)+\alpha_{3}\left(\mathrm{PPE}_{\mathrm{it}} / \mathrm{A}_{\mathrm{it}-1}\right)
$$

3. Calculating non-discretionary accruals (NDA)

$$
N D A_{i t}=\alpha_{1}\left(1 / A_{i t-1}\right)+\alpha_{2}\left(\Delta R_{\text {evit }} / A_{i t-1}-\Delta R_{\text {ecit }} / A_{i t-1}\right)+\alpha_{3}\left(P P E_{i t} / A_{i t-1}\right)
$$

The parameter values $\alpha 1, \alpha 2$, and $\alpha 3$ are the results of calculations in step 2 . Fill in all the values in the formula so that the NDA value will be obtained.

4. Determining the value of non-discretionary accruals which is an accrual earnings management indicator by reducing total accruals with non-discretionary accruals, with the formulation:

$$
\mathrm{DA}_{\mathrm{it}}=\mathrm{TA}_{\mathrm{it}}-\mathrm{NDA}_{\mathrm{it}}
$$

Where:

$\mathrm{TA}_{\text {it }}=$ Total company accrual $i$ in period $t$

$\mathrm{Ni}_{\mathrm{it}}=$ Net income of company $i$ in period $t$

$\mathrm{CFO}_{\text {it }}=$ Operational cash flow of company $i$ in period $t$

$\mathrm{NDA}_{i t}=$ Non-discretionary accrual of company $i$ in period $t$

$\mathrm{DA}_{\text {it }}=$ Corporate $i$ discretionary accrual in period $t$ 
$A_{\text {it-1 }}=$ Total assets of company $i$ in period $t-1$

$\Delta \mathrm{R}_{\text {evit }}=$ Changes in net sales of company $i$ in period $t$

$\Delta \mathrm{R}_{\text {ecit }}=$ Changes in company receivables $i$ in period $t$

$\mathrm{PPE}_{\mathrm{it}}=$ Property, plant and equipment company $i$ in period $t$

$\alpha_{1}, \alpha_{2}, \alpha_{3}=$ Parameters obtained from the regression equation

\subsection{Hypothesis}

Managers as agents are motivated to make tax savings because humans will tend to want to get as much results as possible by removing resources as low as possible. But on the other hand managers also have to manage their profits so that the achievement of profit is on target, because performance measurement will be measured through the achievement of profit. The earnings management technique used by managers to take advantage of this tariff reduction is by way of realistic accruals. Richardson and Lanis (2007) who find evidence that tax reform in Australia has a significant impact on corporate profits. This result shows that tax reform can be used by managers as taxpayers to move profits to periods where tax rates are lower. A similar study was also conducted by Yulianti and Christine (2012) proving that the average company undertakes accrual policy which results in smaller profits in the period where the tax rate is lower. But this is not proven for measurements that use the Lopez accrual model. Ristiyanti and Syafruddin (2012) also reveal that companies that experience profits are proven to do earnings management when there is a decrease in tax rates.

From the explanation above which describes the relationship of earnings management with a decrease in tax rates, so that researchers formulate a hypothesis that is, there are differences in the level of earnings management in the three eras of tax reform.

\section{Methods}

This study uses a quantitative approach. In this study explain the differences in the level of earnings management in the three eras of tax reform, namely based on Law Number 10 of 1994, Law Number 17 of 2000 and Law Number 36 of 2008 which are divided into two, namely to apply a single tariff of $28 \%$ in 2009 and a single tariff $25 \%$ in 2010 with a case study approach in Indonesia.

The type of data used in this study is secondary data. This secondary data is in the form of financial statements as well as annual reports of corporate taxpayers listing on 
the Indonesia Stock Exchange from 1994 to December 2016. The data sources in this study were obtained from the Indonesian Capital Market Directory contained on the website www.ticmi.co.id and the Indonesia Stock Exchange (IDX) found on the website www.idx.co.id.

Population is a generalization area consisting of objects/subjects that have certain qualities and characteristics set by researchers to be studied and then conclusions drawn (Sugiyono, 2014: 61). The population in this study is a Go Public Company listed on the Indonesia Stock Exchange.

Samples are part of the number and characteristics possessed by the population (Sugiyono, 2014: 62). purposive samples, namely the determination of samples based on certain criteria. The criteria in question are based on certain judgment or certain quota. In determining the sample whose data will be processed in this study, the criteria are set as follows:

1. The selected company is a sample that must remain in the list of Indonesian Stock Exchanges during the study period, namely 1994 to 2016.

2. Financial companies are excluded from the sample.

3. Published financial statements from 1994-2016

Data collection techniques in this study were carried out by:

Secondary data needed in this study is obtained through the study of documentation. Documentation is a collection of data by studying or examining written documents or sources as well as other archives in accordance with the research. This collection technique is by collecting financial reports, annual financial reports, and other required data. This study uses financial report data and/or annual reports of non-financial companies from 1995-2015 sourced from the Indonesian Capital Market Directory and Indonesian Stock Exchange (IDX) website.

This study measures earnings management by calculating the Jones discretionary accrual model that has been modified by Dechow and friends (1995). The modified Jones Model (1995) is formulated as follows:

1. Determine the total accrual value (TA)

$$
\mathrm{TA}_{\mathrm{it}}=\mathrm{Ni}_{\mathrm{it}}-\mathrm{CFO}_{\mathrm{it}}
$$

2. Specifies the parameter value $\alpha 1, \beta 1$, and $\beta 2$

$$
\mathrm{TA}_{\mathrm{it}}=\alpha_{1}+\alpha_{2} \Delta \mathrm{R}_{\text {evit }}+\alpha_{3} \mathrm{PPE}_{\mathrm{it}}
$$


Then, for the scale of the data, all these variables are divided by the assets of the previous year (Ait-1), so that the formulation changes to:

$$
\left.\mathrm{TA}_{\mathrm{it}} / \mathrm{A}_{\mathrm{it}-1}=\alpha_{1}\left(1 / A_{\mathrm{it}-1}\right)+\alpha_{2} \Delta \mathrm{R}_{\mathrm{evit}} / \mathrm{A}_{\mathrm{it}-1}\right)+\alpha_{3}\left(\mathrm{PPE}_{\mathrm{it}} / \mathrm{A}_{\mathrm{it}-1}\right)
$$

3. Calculating non-discretionary accruals (NDA)

$$
N D A_{i t}=\alpha_{1}\left(1 / A_{i t-1}\right)+\alpha_{2}\left(\Delta R_{\text {evit }} / A_{i t-1}-\Delta R_{e c i t} / A_{i t-1}\right)+\alpha_{3}\left(P P E_{i t} / A_{i t-1}\right)
$$

The parameter values $\alpha 1, \alpha 2$, and $\alpha 3$ are the results of calculations in step 2 . Fill in all the values in the formula so that the NDA value will be obtained.

4. Determining the value of non-discretionary accruals which is an accrual earnings management indicator by reducing total accruals with non-discretionary accruals, with the formulation:

$$
\mathrm{DA}_{\mathrm{it}}=\mathrm{TA}_{\mathrm{it}}-\mathrm{NDA}_{\mathrm{it}}
$$

\section{Results and Discussions}

\subsection{Analysis of variance (ANOVA)}

\subsubsection{Test of between-subject effects}

From the results of the ANOVA table, it is known that the $p$-value of $F$ test statistics is $0.000(<0.05)$, the conclusion is that the null hypothesis is rejected. This means that there are significant differences in the results of the average value of discretionary accruals in the three era of tax reform.

\subsubsection{Post Hoc test}

The use of Analysis of Variance (ANOVA) in this study is to analyze whether or not there is a significant difference in the level of earnings management as measured by discretionary accruals when the new corporate tax rate decreases. If the value of the ANOVA table $p$-value is smaller than that of 0.05 then Post Hoc Multiple Comparation can be used, which is a follow-up comparison to see which categories have significant differences.

From the $p$-value in the Multiple Comparison table, it is known that the significant difference in the value of discretionary accruals is the reform of the 1994 Act with the reform of the Law in 2000, the reform of the 1994 Act with the reform of the Law of 
$200828 \%$ tariff, and reform of the 1994 Law with the reform of the 2008 Law rates $25 \%$. Meanwhile, the comparison of the average value of discretionary accruals on the Law reform in 2000 with the reform of the 2008 Law rates $28 \%$ and $25 \%$, and the reform of the 2008 Law rates $28 \%$ with $25 \%$ not significantly different from the alpha level. $5 \%$. To see a comparison of the variations in the value of discretionary accruals in the three eras of tax reform in the form of graphs, it can be indicated by the Mean Plot analysis.

The results of this study indicate that one of the four categories of tax reform shows a significant difference in the level of earnings management measured using discretionary accruals. The average level of earnings management that is significantly different occurs in category one (UU95), namely in 1995 when the application of Law Number 10 of 1994. While in category two (UU01), category three (UU28\%), and category four (UU25\%) does not indicate a significant difference. Given that one of these differences means that hypotheses are accepted, that is, there are differences in the level of earnings management in the three tax reform era.

This difference in the level of earnings management proves that the results of the study are in accordance with the statement that earnings management practices do not always appear or in other words earnings management appears in one particular economic activity, but not in other activities (Gumanti, 2000). The decrease in the tax rate of this agency does not affect the practice of earnings management, so that the practice of earnings management cannot be attributed to the reasons for not achieving State income through the tax sector.

In 1995, when Law Number 10 of 1994 was applied, the average discretionary accrual was -1.4623 , which means that the average company made a profit reduction strategy. The decrease in profits that occur is smaller when compared to other categories of years. This happened because in 1995 Indonesia's economic condition had not been hit by the monetary crisis. The Government in 1995 economic growth in Indonesia showed the highest rate of $8.22 \%$. In this year's period the government focused on development in the economic sector related to industry and agriculture. The purchasing power of the people in this era is also quite high so as to create economic stability. The stable condition of the Indonesian economy does not have a significant impact on corporate profits.

In 2009, where Law Number 26 of 2008 was implemented with a single tax rate system of $28 \%$, the average discretionary accrual was increasingly minus, which was equal to -2,681. In 2009 Indonesia was separated from the impact of the 1998 monetary crisis. So the researchers concluded that the accrual value in 2009 declined not because of the impact of the monetary crisis but because the company made a strategy to reduce 
profits for tax motivation. This research is comparable with the research of Ristiyanti and Syafruddin (2010) which states that profit companies in 2007, 2008, 2009, and 2010 were proven to do earnings management in terms of decreasing tax rates.

In 2010, where a single tariff of $25 \%$ was applied, accrual value still showed a minus number even though it decreased compared to 2009. Accrual values in 2010 showed an average of -2.3724 . Even though the tax rate in 2010 was smaller than in 2009 it did not further decreases profits. This is due to the existence of regulations in Law Number 36 of 2008 article 17 paragraph (2b), namely:

Domestic corporate taxpayers in the form of public companies with at least $40 \%$ (forty percent) of the total paid-up shares traded on stock exchanges in Indonesia and meeting certain other requirements can obtain a tariff of $5 \%$ (five percent) lower than the tariff as referred to in paragraph (1) letter $b$ and paragraph (2a) which are regulated by or based on Government Regulations.

If the company meets these requirements, the company can pay only $20 \%$ (twenty percent) of the tax. One of the conditions for obtaining a tariff of $20 \%$ (twenty percent) at least the company must have at least $40 \%$ (forty percent) of the paid-up shares. To have $40 \%$ (forty percent) of shares paid by the company must be able to attract investors to invest in their company. One way to attract investors is by showing a good profit performance, namely by showing a higher profit value compared to the value of earnings in the previous period. So, in $\mathbf{2 0 1 0}$ the company tended to increase profits compared to 2009 to get a $20 \%$ (twenty percent) tax incentive opportunity compared to having to reduce profits.

The difference in the level of earnings management in these four categories shows that tax motivation is not the only motivation that makes management as an agent to make a profit reduction strategy. The instability of the economic condition is a matter of consideration for managers to implement earnings management strategies. Up and down economic conditions make the value of shares also experience ups and downs. To continue to show good performance to shareholders, managers must maintain their profits. This may be in line with opinion (Schipper, 1989) in (Gumanti, 2000) that certain events or events can influence the manager's decision to regulate or manage, whether by increasing or decreasing reported profits with certain motivations, which is driven by personal or corporate benefits. Before practicing earnings management, managers as agents will also consider the conditions of the shareholders as principal. After weighing the conditions of the shareholders, managers will also select the optimal accounting 
procedures for an existing purpose. In accordance with a positive approach in accounting, that management must explain and predict standard choices through analysis of the costs and benefits of certain financial disclosures. One of them is the selection of accounting standards in corporate earnings reporting.

\section{Conclusions and Recommendations}

Based on the results of testing the hypothesis, the results show that there is a significant difference in the level of accrual accruals in 1995. The researchers analyzed this difference due to different economic conditions in 1995, 2001, 2009, and 2010. Thus, there was a decrease in income tax rates when it occurred Tax reform does not make managers carry out tax-motivated earnings management actions. In managing company profits managers will consider other factors that are deemed necessary to benefit the shareholders as principals and managers as agents. One factor considered is the economic condition.

Based on the research conducted, the researchers provide suggestions for further research as follows:

1. This study only analyzes the level of earnings management after applying a tax rate reduction. Future research can add years where the Tax Law still has not been implemented. So that further research is expected to complement the results of this study by describing the level of management before and after the implementation of the new income tax rate.

2. The results of this study are expected to be an input for the government to review the implementation of the reduction in tax rates to increase tax revenues. In order for tax revenues to increase, the government can use other methods, one of which is to improve economic stability.

\section{References}

[1] Badertscher, B., et al. (2009). Earnings management strategies and the trade-off between tax benefits and detection risk: To conform or not to conform? American Accounting Association, vol. 84, no. 1, pp. 63-97.

[2] Belkaoui, R. A. (2011). Accounting Theory Teori Akuntansi (Edisi 5). Buku Satu, Jakarta: Salemba Empat. 
[3] Comprix, J., et al. (2012). Bias in Quarterly estimates of annual effective tax rates and earnings management. American Accounting Association, vol. 34, no. 1, pp. 31-53.

[4] Friskianti, Y. and Handayani, B. D. (2014). Pengaruh Self-Assessment System, Keadilan, Teknologi Perpajakan, Dan Ketidakpercayaan Kepada Pihak Fiskus Terhadap Tindakan Tax Evasion. Accounting Analysis Journal, vol. 3, no. 4, pp. 543-552.

[5] Ghozali, I. (2012). Aplikasi Analisis Multivariate dengan Program IBM SPSS. Semarang: Badan Penerbit Universitas Diponegoro.

[6] Gumanti, T. A. (2000). Earnings management: Suatu telaah pustaka. Jurnal Akuntansi \& Keuangan, vol. 2, no. 2, pp. 104-115.

[7] Hutagaol, J. (2007). Perpajakan Isu-isu Kontemporer. Yogyakarta: Graha IImu.

[8] Jensen, M. C. and Meckling, W. H. (1976). Theory of the firm: Managerial behavior, agency costs and ownership structure. Journal of Financial Economics, vol. 3, no. 1, pp. 305-360.

[9] Lin, B., et al. (2012). Tax-induced earnings management in emerging markets: Evidence from China. American Accounting Association, vol. 34, no. 2, pp. 19-44.

[10] Richardson, G. and Lanis, R. (2007). Determinants of the variability in corporate effective tax rates and tax reform: Evidence from Australia. Journal of Accounting and Public Policy, vol 26, pp. 689-704.

[11] Ristiyanti, A. W. and Muchamad, S. (2012). Manajemen Laba Sebagai Respon Perubahan Tarif Pajak Penghasilan Badan Pada Perusahaan Manufaktur yang Terdaftar di BEl. Diponegoro Journal of Accounting, vol. 1, no. 2, pp. 1-15.

[12] Scott, W. R. (2003). Financial Accounting Theory. United States of America: Prentice Hall.

[13] Siregar, S. S. (2014). Statistik Parametik untuk Penelitian Kuantitatif Dilengkapi dengan Perhitungan Manual dan Aplikasi SPSS Versi 17. Jakarta: Bumi Aksara.

[14] Suandy, E. (2014). Perencanaan Pajak. Jakarta: Salemba Empat.

[15] Sugiyono. (2014). Metode Penelitian Kuantitatif Kualitatif dan R\&D. Bandung: Alfabeta.

[16] Sulistiawan, D., et al. (2011). Creative Accounting: Mengungkap Manajemen Laba dan Skandal Akuntansi. Jakarta: Salemba Empat.

[17] Yulianti and Christine. (2008). Pengaruh Penurunan Tarif Pajak dalam UndangUndang Pajak Penghasilan Tahun 2008 Terhadap Kebijakan Penyusunan Laporan Keuangan, in Seminar Akuntansi Nasional XV.

[18] Retrieved from: http://www.idx.co.id

[19] Retrieved from: http://www.ticmi.co.id 
[20] Retrieved from: http://wartakota.tribunnews.com

\section{Regulations and Rules}

Undang-Undang Nomor 7 Tahun 1983 sebagaimana yang telah diubah terakhir kali dengan Undang-Undang Nomor 36 Tahun 2008 tentang Pajak Penghasilan.

Peraturan Menteri Keuangan Nomor 238/PMK.03/2008 tentang Tata Cara Pelaksanaan dan Pengawasan Penurunan Tarif Bagi Wajib Pajak Badan Dalam Negeri yang Berbentuk Perseroan Terbuka. 